\title{
Plant Protection for Pistachio
}

Brent A. Holtz

\begin{abstract}
Additional index words. Pistacia vera, Botryosphaeria, Verticillium, Alternaria, Phytocoris, Neurocolpus, Calocoris, Lygus, Thyanta, Chlorochroa, Acrosternum, Leptoglossus, Amyelois, Choristonuera
\end{abstract}

Summary. Pistachio (Pistacia vera) was successfully introduced into California and initially touted as a tree nut crop with no disease or insect pests. Unfortunately, these expectations were dashed as a number of diseases and pests followed commercial plantings, making plant protection practices integral to production. Verticillium wilt (Verticillium dabliae) devastated early plantings but is now controlled with the use of resistant rootstocks. Botryosphaeria blight (Botryosphaeria dothidea) and alternaria late blight (Alternavia alternata) are recently arrived foliar fungal diseases that blight fruit clusters and defoliate trees, respectively, and multiple fungicide applications are needed for control. The conversion to low volume irrigation systems, specifically to drip or buried drip, has reduced disease. Pruning out botryosphaeria blight infections has reduced overwintering inoculum and disease, while current research aims at accurately predicting infection events to increase fungicide efficacy. A number of hemipteran insect pests have been associated with epicarp lesion: spring treatments have been replaced with dormant carbaryl and oil applications which are less toxic to beneficial insects while controlling phytocoris (Phytocoris californicus and P. relativus) and soft scale pests. Early season insect damage can be tolerated because trees compensate by maturing a higher percentage of remaining fruit kernels. Some mirid (Calocoris spp.) pests can be effectively reduced by eliminating alternate hosts in an effective weed control program. If lygus (Lygus hesperus) populations are present, weeds should not be disturbed from bloom until shell hardening to prevent movement by insects into the trees where feeding can result in epicarp lesion. Stink bugs (Pentatomidae) and leaffooted bugs (Leptoglossus clypealis and L. occidentalis) can penetrate the hardened shell and cause internal nut necrosis along with epicarp lesion. Trap crops are used to monitor pest populations in order to develop treatment thresholds. Degree-day based timing of treatments increase insecticide efficacy for the control of navel orangeworm (Amyelois transitella) and obliquebanded leafroller (Choristonueva rosaceana), but navel orangeworm populations are more effectively managed by destroying unharvested over wintering fruit. Bacillus thuriengiensis sprays, liquid-lime-sulfur, and biological control show promise in controlling obliquebanded leafroller.

$\mathrm{P}$ istachio is a dioecious plant native to western Asia, first introduced into California in 1890. There was little interest in the crop until the high-quality 'Kerman' cultivar was released in 1957 and later shown to yield nicely in California (Ferguson, 1998). Two cultivars, Kerman (female) and Peters (male) are used in commercial orchards. Yields in California have risen from $680,000 \mathrm{~kg}(1.5$ $\left.\times 10^{6} \mathrm{lb}\right)$ in 1967 to more than $108 \times 10^{6} \mathrm{~kg}\left(240 \times 10^{6} \mathrm{lb}\right)$ in 2000 (California Pistachio Commission, 2001). Coincidental to the 'Kerman' release was the completion of the Oroville Dam in 1967 and the California Aqueduct System which provided a new source of water to irrigate orchards in the lower west side of the San Joaquin Valley. In 1976 the California Pistachio Association was formed to assess growers and processors to support production research and to educate growers and the general public about pistachio.

Pomology farm advisor, University of California Cooperative Extension, 328 Madera Ave., Madera CA, 93637; baholtz@ucdavis.edu. Information was provided for this manuscript by Bob Beede, Kent Daane, Pete Goodell, Walt Bentley, Themis Michailides, Mark Doster, Louise Ferguson, and Richard Rice. A special thanks to Beth Teviotdale for editing this manuscript. 


\section{Diseases}

Verticillium wilt. During the relatively short time that pistachio trees have been grown in California, verticillium wilt has been the most serious disease causing the greatest economic loss to growers. Verticillium wilt is caused by the soilborne plant pathogenic fungus Verticillium dabliae (Raabe and Wilhelm, 1978). Pistachio trees of any age are susceptible, and hundreds die every year. Infected branches and trees collapse or wilt with the first warm weather of the season. Verticillium dabliae does not cause root or bark rot. It invades the tree's roots and colonizes the vascular system, clogging and discoloring the xylem, and preventing normal water transport. Verticillium dabliae survives in the soil as a microsclerotium, which is a cluster of small hyphal cells that are extremely hardy and able to survive for long periods in the absence of a susceptible host (Huisman and Ashworth, 1974). The fungus also survives on the roots of a number of alternate hosts. Wilt is often more severe in orchards that were previously planted to a susceptible host crop such as cotton. Microsclerotia remain quiescent in the soil until exudates from a nearby root of a susceptible host stimulate them to germinate. Verticillium wilt is favored by cool temperatures and wet soil. Plant vigor affects susceptibility, with stressed trees more vulnerable than healthy. The best defense against verticillium wilt is the use of resistant rootstocks. 'Pioneer Gold' (Pistacia integerrima) and 'UCB-I' (P.atlantica $\times P$. integerrima hybrid) are currently the only resistant rootstocks used in California (Morgan et al., 1992). The nature of resistance to verticillium wilt is not understood. The fungus is able to invade the roots of both susceptible and resistant plants. Once inside the xylem, the movement of the fungus up the vascular tissues is much slower in the resistant rootstocks.

Panicle and shoot blight. In Summer 1984 another devastating fungal pathogen was first isolated from blighted pistachio fruit and shoots. Botryosphaeria dothidea, a foliar plant pathogenic fungus was identified as the causal agent (Michailides, 1991). The fungus specifically attacks and kills fruit clusters and yield losses of $40 \%$ to $100 \%$ are not uncommon (Michailides, 1991). The fungus is also capable of attacking male inflorescences before they dehisce available pollen, further reducing production. Earlier reports of botryosphaeria on more than 35 different plants species in California suggest that the pathogen was present before pistachios were extensively planted in the 1970s (Ma et al., 2001a).

Symptoms appear in mid to late spring, usually as black 1 to $2 \mathrm{~mm}$ ( 0.04 to 0.08 inch) circular spots on shoots, rachises, and leaves. Lesions on petioles can kill individual leaflets and defoliation may take place by late summer. Leaves near infected fruit clusters quickly wither and brown and are distinct when observed next to lush green foliage. Infected rachises collapse. Initial fruit infections appear in early summer as pin-sized round black dots (Michailides, 1991). Lesions on infected fruit may enlarge and turn the fruit black and silver, ultimately spreading into the peduncle and rachis. Some infected fruit will turn silver gray and be associated with the production of pycnidia by the pathogen. The dead black rachises, which are left on the tree after harvest and through the winter, serve as an inoculum source and are a good diagnostic symptom for disease identification. The pathogen can spread from infected rachises or leaves into shoots, causing shoot infections, from which cankers and pycnidia can be produced.

Conidia released from pycnidia present on the previous year's blighted buds, shoots, petioles, rachises, fruit, and cankers cause primary infections in spring and summer. New pycnidia in current season infections serve as inoculum sources for late summer and fall infections. Conidia are spread by rain, insects, birds, and water from sprinkler irrigation. Rain anytime during the growing season can spread inoculum and increase the likelihood of disease. Fall and winter rains spread conidia to leaf and bud scars and dormant buds. Buds become infected and die or appear healthy but harbor the pathogen until spring. Botryosphaeria dothidea prefers warm temperatures and high humidity, and as a consequence, warm humid weather in spring and summer enhance disease severity (Michailides and Morgan, 1992).

Panicle and shoot blight can be very difficult to control, especially if the disease has increased unchecked in an orchard over several years and a large number of overwintering can- kers or inoculum sites have developed. The best control program employs a combination of measures that include fungicide sprays and pruning to remove inoculum sources along with irrigation management (Michailides and Morgan, 1993). Multiple applications of strobilurin (azoxystrobin) and sterol demethylation inhibitor fungicides have shown efficacy in summer applications. An additional application of benomyl during bloom for botrytis blossom and shoot blight (Botrytis cinerea) has also been found to reduce botryosphaeria blight (Michailides et al., 1997). Pruning out blighted shoots and panicles reduces disease and is economically justifiable (Holtz et al., 2001a). In orchards irrigated with sprinklers, lowering the sprinkler angle so that water does not reach the tree canopy or shortening the duration of an individual irrigation reduces disease (Michailides and Morgan, 1993). Current research is underway to determine the genetic relationships among various botryosphaeria isolates from pistachio and other hosts and to develop a predictive model so that growers can better time fungicide applications ( $\mathrm{Ma}$ et al., 2001b).

Alternaria late blight. Alternaria late blight is another serious fungal foliar disease of pistachio caused by Alternaria alternata. Severe infections result in shell staining and early defoliation that can weaken trees and reduce yields. Symptoms appear on leaves in mid summer as small dark brown to black angular or circular lesions just a few millimeters in size. Lesions can expand in diameter to 2.5 to $3.0 \mathrm{~cm}$ ( 1.0 to 1.2 inch) in size. Dense sporulation develops on lesions, turning them and leaves black. Lesions on fruit, especially on fruit with ruptured hulls (early splits), often results in shell staining (Michailides, 2003).

High relative humidity and dew favor alternaria late blight. The disease gradually becomes worse as the season progresses, and aging leaves and fruit become more susceptible to infection. Alternaria is a very common fungus in nature and its spores can be found from early April to harvest on pistachio leaves, crop debris of all kinds, and on weeds. Male trees (pollinizers) are often severely infected compared to females. Alternaria late blight can be more severe on fruit-bearing shoots when compared to nonfruiting shoots, as trees stressed with crop load are 
often the most severely infected (Michailides, 2003).

Alternaria late blight of pistachio is difficult to control. Disease management usually requires a combination of fungicide applications along with reducing irrigation frequency and duration in early August when trees are more susceptible. Azoxystrobin, chlorothalonil, iprodione, tebuconazole, or trifloxystrobin applied two or three times in July and August have been shown to reduce disease. Fungicide applications aimed at reducing botryosphaeria blight also reduce alternaria blight. Curtailing irrigation in early August and using irrigation systems that allow the soil surface to dry more quickly are recommended (Michailides et al., 1996). Orchards with no cover crop or those irrigated by drip, microsprinkler, or subsurface systems have less alternaria blight when compared to flood or sprinkler irrigated orchards. Harvest delays should be avoided to minimize disease severity.

\section{Insects}

The small bugs. Feeding by several small plant bug species on pistachio fruit before shell hardening can result in epicarp lesion. Symptoms of epicarp lesion include dark shriveled fruit with localized pitting and a darkened area in the shell (Rice et al., 1988a). The small bugs can penetrate the fruit only before the shell hardens. After shell hardening the small bugs can no longer damage the pistachio nut. Small bug damage is dependent on seasonal population fluctuations.

Phytocoris. Phytocoris californicus and $P$. relatious are the phytocoris pest species of pistachio in California (Beede, 2003). In addition to feeding on pistachio fruit and leaves, phytocoris can be a predator of other insects, including other pistachio pests such as navel orangeworm and a number of soft scales. Phytocoris species overwinter in the egg stage on 1-yearold fruit wood. Most eggs are laid in the bark tissue within a tubelike structure capped at the bark surface. In California, Phytocoris species usually have four generations per year, sometimes five when the weather is unseasonably warm.

Treatment for phytocoris with permethrin between fruit set and late April is common, usually after epicarp lesion or the presence of phytocoris has been observed. Phytocoris populations have been observed to return in even higher numbers after a permethrin treatment than they were before, presumably due to the resurgence of the pest in the absence of its natural enemies. In such cases a second permethrin treatment is often necessary. Permethrin treatments have substantially increased soft scale populations feeding on 1 -year-old fruiting wood (Beede et al., 1995). The soft scale pests include european fruit lecanium scale (Parthenolecanium corn), frosted scale (Parthenolecanium pruinosum), and black scale (Saissetia oleae).

An alternative to treating phytocoris with permethrin in April is the application of carbaryl and oil during the dormant season, most effectively from mid-December to midFebruary. This dormant application significantly reduces soft scale species as well as phytocoris and is softer on beneficial insects that are important in maintaining low phytocoris populations (Beede et al., 1996). More epicarp lesion is often observed on fruit following the dormant carbaryl and oil application, but this loss is offset by the trees ability to compensate for fruit lost prior to shell hardening by setting and filling fruit that otherwise would have been shed naturally due to competition (Beede, 2003).

Neurocolpus. The california buckeye bug or neurocolpus (Neurocolpus longirostrus) is a native insect common throughout the Sierra Nevada and coast range foothills of California. Neurocolpus is found primarily on california buckeye (Aesculus californica) and sometimes on coffeeberry (Rhamnus spp.). Epicarp lesion and crop losses due to this pest are found only in regions close to native buckeye. Damage from neurocolpus can be as high as 30\% to 35\% (Rice, 2003).

Neurocolpus overwinters in the egg stage on both buckeye and pistachio, and has one generation per year in Calif. Females lay their eggs at the base of new growth leaf petioles or terminal buds. Egg hatch usually coincides with buckeye flowering at various elevations or with pistachio bloom in April. Adult neurocolpus can migrate more than $400 \mathrm{~m}$ (1/4 mile) from native buckeye to commercial pistachio orchards, appearing in beating tray samples from early May until shell hardening, which is usually late May or early June (Rice, 2003). While adults are present in pistachio orchards they may lay overwintering eggs, and if juveniles become established, neurocolpus can maintain itself as an endemic pest. The most distinguishing characteristic of neurocolpus adults and nymphs is the enlarged first antennal segment that appears fuzzy or hairy under magnification.

Neurocolpus damage appears inside the shell as distinct cavities or pits in the soft shell tissue and externally as darkening, concentric (zonate) rings or stains typical of epicarp lesion. There are no treatment threshold levels for neurocolpus in pistachio orchards. Once neurocolpus is found its potential to severely impact soft shelled nuts and become endemic is so great that chemical control, usually with permethrin, is required (Rice, 2003).

Calocoris. The potato mired or calocoris (Calocoris norvegicu) is a recent introduction to North America. Calocoris is more numerous in the northern Sacramento Valley than in the southern San Joaquin Valley (Rice et al., 1985). Losses as high as 48\% have been reported from pistachio orchards in the Sacramento Valley where high populations went uncontrolled (Purcell and Welter, 1991).

Calocoris has only one generation per year and overwinters in the egg stage in the stems of weed hosts and not in pistachio. Nymphs appear in late March in the Sacramento Valley, and adults are present from midApril through June. Calocoris prefers native or cultivated legumes such as purple vetch (Vicia benghalensis), clovers (Trifolium spp.), and alfalfa (Medicago sativa); broad-leaved weeds such as mustard (Brassica campestris), fireweed (Epilobium angustifolium), london rocket (Sisymbrium irio), and curly dock (Rumex crispus). Populations of calocoris decline and disappear with the maturing and drying of native weed hosts in late spring and early summer. At this time adult calocoris migrate into pistachio trees and cause early season epicarp lesion before shell hardening. Calocoris does not have a strong affinity or continual association with pistachio, rather its population builds up on weeds in and around pistachio orchards. Within pistachio orchards, cover crops and weeds can sustain adult populations of calocoris for extended periods. Adults 
have been observed in orchards during the day, migrating between ground covers and nut clusters in the trees (Purcell and Welter, 1990). A direct correlation has been shown between populations of calocoris in weeds and alfalfa and epicarp lesion damage in adjacent pistachios trees.

Control of calocoris is best achieved by reducing weed hosts in and around pistachio orchards prior to the maturing of nymphs. Weed hosts should be cultivated or treated when fourth or fifth instar nymphs are first detected in sweep samples. Effective weed control should reduce or eliminate the need for insecticide sprays. Calocoris is often only found within $90 \mathrm{~m}(300 \mathrm{ft})$ of an orchard border, thus making border insecticide applications more desirable and as effective as spraying the entire orchard (Rice, 2003).

Lygus. The western tarnished plant bug or lygus (Lygus hesperus) is native to the San Joaquin Valley of California and has a reported host range of 110 plant species. Lygus bugs are also pests of cotton (Gossypium barbadense and $G$. hirsutum), alfalfa, strawberries (Fragaria spp.), bean (Phaseolus spp.), apple (Malus domestica), pear (Pyrus communis), celery (Apium spp.), broccoli (Brassica oleracea var. italica), cauliflower (Brassica oleracea var. botrytis), and vegetable seed crops, but usually do not like grasses. Other hosts include sugar beets (Beta vulgaris), tomato (Lycopersicon esculentum), grape (Vitis vinifera), row crops, and orchard weeds. Lygus is brown with a gold straw like mottling about $0.6 \mathrm{~cm}(1 / 4$ inch) in length. Lygus damages fruit by feeding before shell hardening which can cause epicarp lesion. Damage is determined by the proximity of pistachio orchards to host plants that could support lygus populations before migration.

Lygus overwinter as adults on host plants and ground covers outside of pistachio orchards and move to a variety of host plants, including pistachio, in the spring. Lygus populations are dependent on environmental conditions, such as rainfall and temperature, that favor the emergence and establishment of broadleafweeds. The number of generations occurring each spring is determined by temperature. Developmental thresholds for lygus range from 8 to $12^{\circ} \mathrm{C}$ (46.4 to 53.6 $\left.{ }^{\circ} \mathrm{F}\right)$ (Champlain and Butler, 1967). In the fall, premature adults enter a sexual diapause stage as daylight hours decrease. The arrested development is broken in December when adults begin moving and feeding again. Eggs of the first generation are laid on available hosts and the cycle begins anew. In California, few wild hosts survive past June and as a result lygus bugs usually move from them in April and May. Russian thistle or tarweed (Hemizonia kelloggii) and alfalfa are preferred hosts (Goodell et al., 2000).

Another important source of lygus can be weeds and cultivated cover crops growing on an orchard floor. Weed species usually become unattractive during dry years just as pistachio fruit clusters become susceptible. It is important to not disturb weed hosts during the period from bloom through shell hardening to avoid driving lygus into the trees where their feeding can cause epicarp lesion.

Only the adults are capable of flying from host plants into pistachio orchards. Before a migration adults develop wing pads that are visible. If lygus is monitored closely and sprayed before a migration, it can be controlled. Detection within the pistachio canopy using a beating tray is much more difficult compared to sweeping ground vegetation. There are no current thresholds, but if the decision to spray is made, timing should be based on the development of adults in nearby weed hosts (Goodell and Bentley, 2003). If visible epicarp lesion is increasing within an orchard and adult lygus can be found, treatment of the orchard is usually necessary. Innovative growers plant trap crops that they monitor carefully and spray, if necessary, before a migration occurs. Permethrins are the most effective materials for lygus control (Goodell and Bentley, 2003).

The Large Bugs. Several plant bug species in the Pentatomidae and Coreidae families are referred to as large bugs and their feeding on pistachio fruit before shell hardening also causes epicarp lesion. Unlike the small bugs, the large bugs can continue to puncture fruit through the hardened shell and into the kernel. Large bug feeding, after shell hardening, causes a pocket of necrotic material to form which results in kernel necrosis. A yeast may infect and stain fruit after feeding, a condition referred to as stigmato- mycosis, if stink bug mouthparts were contaminated (Michailides and Morgan, 1990). The large bugs may also carry botryosphaeria spores if the disease is present in an orchard, and may facilitate fungal entry by providing entry and germination sites (Michailides et al., 1987). Feeding after shell hardening by the large bugs can reduce yields more than small bug feeding, since there is no compensation from unfilled nuts at this time and damaged nuts remain in the cluster and lover overall fruit yield and marketability.

Large bugs in the family Pentatomidae that are pistachio pests include the red-shouldered stink bug (Thyanta pallidovirens), uhler's stink bug (USB) (Chlorochroa ubleri), say's stink bug (SSB) (C. sayi), and the flat green stink bug (Acrosternum hilare). Pests in the Coreidae family are the leaffooted bugs (Leptoglossus clypealis and L. occidentalis). Adults in the Pentatomidae are often difficult to separate; the two most closely related species are the USB and SSB. The membranous portion of the wing of the USB is transparent or whitish while the SSB is purplish. Of these two, the USB is more commonly found in pistachio orchards (Daane et al., 1999). The flat green stink bug is a large deepgreen stink bug with a flat oval back. The adult red-shouldered stink bug is easily separated from the other adult stink bugs by the red stripe across its shoulder. The two leaffooted plant bugs are easily recognized by the leaflike flattened extensions on their hind legs. The leaffooted plant bugs are longer, narrower, and darker than the other stink bugs. Leptoglossus clypealis is more common in pistachio than $L$. occidentalis, and has a sharp point on the front of its head while L. occidentalis lacks this point. The large bugs pass through five distinct immature or nymphal stages that differ from each other and the adult stage (Daane et al., 2003). The above descriptions pertain only to adult bugs.

The large bugs overwinter inside and outside the orchard and immigrate or emigrate in large numbers as adults, causing severe damage in a short time. Unfortunately, migration and feeding patterns of the different bugs are not well understood. Several approaches to avoid triggering the process of migration to the canopy are being considered. In one, alternate host plants outside the orchard are 
identified and destroyed as soon as possible to eliminate the pests; in another, outside plants are maintained in good condition for as long as possible to keep the bugs in them and delay migration into the orchard; and lastly the growth of host plants on the orchard floor is encouraged to attract the bugs and prevent their migration from the floor to the canopy.

The effectiveness of ground vegetation to monitor hemipteran pests and to hold migratory pest populations until an insecticide can be applied is also being studied. Preliminary research showed that rows seeded with mustard attracted and sustained the largest population of bugs, followed by vetch (Vicia sativa), clover, and alfalfa. The majority of red shouldered stink bugs were found in the clover, most of the flat green stink bugs were in vetch, most of the lygus in alfalfa, while calocoris preferred mustard (Daane et al., 1999). The composition of a trap crop can be tailored to suit the insects in a particular orchard.

Because damage ensues quickly after migration into an orchard, quick and accurate sampling methods are needed to detect these hemipteran pests before the orchard sustains economic damage. Most growers use beating trays to sample foliage. Provided that samples are taken frequently and from a large number of trees, the beating tray is a good indicator of which bugs are present and of population changes throughout the season. But the beating tray method is largely ineffective at determining pest densities and poorly estimates pest presence at low densities. Because most bugs will feed on the seeds of ground vegetation, sweep samples best indicate the presence of hemipteran pests in an orchard (Daane et al., 2003). Pyrethroids are effective and commonly used, however research is needed to determine economic injury levels to determine application timings (Daane et al., 1999).

Navel orangeworm. The navel orangeworm (NOW) (Amyelois transitella) infests pistachio, walnut (Juglans regia), and almond (Prunus dulcis). Damage occurs after the hull has split and exposed the nut within. Pistachio is particularly susceptible to infestation because the shell splits completely before the hull splits, allowing worms to move directly to the kernels where feeding results in unacceptable damage. Moths are attracted to these split hulls where they lay their eggs. Years with abnormally early hull split in pistachio are severe NOW years (Doster and Michailides, 1999). Insufficient spring irrigation may also result in abnormal shell split (Doster et al., 2001). In addition to direct damage by worm feeding, fungal pathogens are also associated with NOW damaged nuts that can result in aflatoxin contamination (Doster and Michailides, 1994).

Navel orangeworm moths are gray with interspersed black zigzag markings across the wing. Moths are about $19 \mathrm{~mm}(3 / 4 \mathrm{inch})$ in length with palpi that form a sharply pointed head. Each female lays an average of 90 eggs that are flat, cream colored, and the size of a pinhead (Zalom et al., 1998). The larvae quickly move into the kernel where they feed, produce webbing, and fecal droppings. The mature larvae are between 16 to $19 \mathrm{~mm} \mathrm{(5/8} \mathrm{to}$ $3 / 4$ inch) in length and pink to pale cream in color. Larvae are characterized by a mahogany brown head and sclerotized "c" shaped markings on the top of the second body segment with true legs.

Information developed for NOW control in almond and walnut is used in pistachio. NOW is best managed by removing the unharvested overwintering fruit from the orchard (Sibbett and Van Steenwyk, 1993). The insect must have a food source on which to overwinter and survive on until hull split. Growers eliminate NOW's food source by removing and destroying unharvested fruit. This requires workers to walk through the orchard during the winter and physically knock unharvested fruit to the ground, and is most effective in orchards that are isolated from other NOW food sources (Bentley and Holtz, 2003; Rice et al., 1988a).

Egg laying can be traced throughout the season by using bait traps which attract females (Rice et al., 1984). Because eggs can hatch in as little as $5 \mathrm{~d}$ during the summer, these traps should be checked twice weekly. Information from egg laying can be used to time insecticide applications. Navel orangeworm develops between the temperature thresholds of 12.7 and $34.4^{\circ} \mathrm{C}\left(55\right.$ to $94^{\circ} \mathrm{F}$ ) (Engle and Barnes, 1983). Using the first egg trapped of each new generation, about 1060 degree-days are required before the first eggs of the next generation are laid (Sanderson and Barnes, 1990).
There are four generations of NOW in the San Joaquin Valley. The most effective time to apply insecticides is when 204 to $260{ }^{\circ} \mathrm{C}$ ( 400 to $500^{\circ} \mathrm{F}$ ) degree-days have accumulated after the beginning of third generation egg laying (Zalom et al., 1998). This generally occurs during early August in the southern San Joaquin Valley.

Fruit harvested late are particularly susceptible to infestations, thus harvesting prior to the beginning of the fourth generation of worms, reduces the exposure time and level of infestation (Connell et al., 1989). There are two parasitoids of NOW commonly found in California; they are copidosoma (Copidosoma plethorica) and goniozus (Goniozus legneri). Both parasites require relatively high pest densities for establishment and they cannot be relied upon alone to control NOW.

Obliquebanded leafroller. The obliquebanded leafroller (OBLR) (Choristonuera rosaceana) has become a major pest of pistachio in the last decade (Rice et al., 1988b). OBLR is widely distributed throughout North America and is also a key pest of apple, pear, and cherry (Prunusavium). Since these crops also are grown in the San Joaquin Valley, it is likely that OBLR moved from one of them and adapted to feeding on pistachio. OBLR is one of the largest lepidopterous pests found in pistachio, the adult moth is about $16 \mathrm{~mm}$ in length. OBLR is bell shaped and has fawn coloration with a distinct inverted dark brown chevron in the middle of the outer wings. Mature larvae are $19 \mathrm{~mm}$ in length, have a shiny black head, and are quite active.

Each female moth can lay up to 200 eggs on leaves and fruit. The egg masses are pale green in color and usually flattened on the green background of the leaf surface, making them difficult to observe. Upon hatching, OBLR larvae distribute and tie two leaves or leaves and fruit together while they feed. Two leaves are usually glued together by the feeding and webbing and the area of feeding is brown and dried. The presence of these tied leaves is a good indicator of OBLR activity and is a good place to capture larvae.

The primary damage caused by OBLR is the destruction of clusters from late May through late July where feeding on the peduncle and outer fruit epidermis can cause fruit drop. 
Often larvae will be found inside the unfilled shell where the embryo was eaten before it could develop. Unlike NOW, OBLR does not invade the developed kernel. When fruit mature, damage by OBLR is minimal, but in cases of severe infestation and leafloss, a reduction in photosynthesis most likely occurs.

When disturbed, OBLR larvae quickly wiggle backwards, and often drop on a slender silk thread. Pupation occurs in damaged clusters or between tied leaves, with the pupal case often protruding from leaves or clusters after moth emergence. OBLR overwinters as a third stage larva in the bud scales and roughened area of the bark. During late March and early April the overwintering larvae emerge and commence feeding on buds and young leaves. Pupation occurs in April and moths emerge in late April or early May. Two distinct peaks are often observed in moth traps during the overwintering flight. The second flight begins in early July and ends in early August. The third and final flight occurs in early September and worms from this flight will overwinter and complete development the following spring. The flight of OBLR can be monitored using pheromone-baited rubber septa placed in various types of winged sticky traps. Traps should be checked twice weekly and the bottoms should be removed after 40 or more moths have been caught.

Insecticides are currently the most effective control for OBLR. Phosmet (Imidan; Gowan, Yuma, Ariz.), tebufenozide (Confirm; Dow AgroSciences, Indianapolis), spinosad (Success; Dow AgroSciences), and Bacillus thuringiensis (Bt) (DiPel; Valent USA, Walnut Creek, Calif. and Deliver; Thermo Triology Corp, Columbia, Md.) have shown efficacy against OBLR. Applications of $B t$ are made in the spring when overwintering larvae emerge but before leaf tying (Li et al., 1995). Because of the long emergence period, multiple sprays may be required. $B t$ is the only registered insecticide available for USDA certified organic growers. Calcium polysulfide (liquid-lime-sulfur) may also show efficacy against OBLR (Holtz et al., $2001 \mathrm{~b})$. Tebufenozide, Bt, and spinosad are not disruptive to beneficial insects.

Current research is aimed at determining optimal timing for degree- day based applications (Onstad et al., 1985). Preliminary data in pistachio suggests that optimal control can be achieved at degree-day timings of between 426.7 to $648.9{ }^{\circ} \mathrm{C}$ (800 to $1200{ }^{\circ} \mathrm{F}$ ) degree-days (Bentley et al., 2001). The first male moth trapped, instead of the first egg of a new generation, is used as the biological fix point to start degree-day calculations. The base temperature for beginning degree-day timings is $6.1{ }^{\circ} \mathrm{C}\left(43{ }^{\circ} \mathrm{F}\right)$. There are about 2000 degree-days between generations.

Biological control of OBLR shows promise in organic orchards where broad-spectrum insecticides are not being used. The most common parasitoid is the polyembrionic wasp macrocentrus (Macrocentrus irredescens) which looks very much like a mahogany brown mosquito. Multiple wasps can be produced from a single egg laid within an OBLR larvae, and parasitism appears to increase as the season progresses (Daane et al., 2001).

\section{Conclusion}

Pistachio has been successfully introduced into California and even though it has not lived up to its initial expectation of being pest free, production continues to increase thanks to continually evolving plant protection practices.

\section{Literature cited}

Beede, R.H., D. Thomas, R.E. Rice, K.M. Daane, J. Padilla, and W.J. Bentley. 1995. Relation of Phytocoris relations to lecanium scale infestation in pistachios, p. 89-99. In: California pistachio industry annual report, Crop year 1994-1995. Calif. Pistachio Comm., Fresno.

Beede, R.H., R.E. Rice, K.M. Daane, D.R. Thomas, J. Padilla, S. Soliman, W. Bentley, and G. Weinberger. 1996. Relation of Phytocoris relativus to lecanium scale infestations on pistachios, p. 107-118. In: California pistachio industry annual report, Crop year 1995-1996. Calif. Pistachio Comm., Fresno.

Beede, R.H. 2003. Phytocorisand soft scale. In: L.E. Ferguson (ed.). Pistachio production manual. Univ. Calif., Div. Agr. Natural Resources, Oakland (in press).

Bentley, W., L. Martin, B. Ribeiro, B. Holtz, and C. Wylie. 2001. Developing insecticide treatment guidelines for Obliquebanded Leafroller, Choristoneura rosaceana, in Pistachio, p. 121. In: California pistachio industry annual report, Cropyear 2000-2001. Calif. Pistachio Comm., Fresno.
Bentley, W. and B. Holtz. 2003. Navel orangeworm, Amyeloistransitella (Walker) and obliquebanded leafroller, Choristonuera rosaceana (Harris). In: L. E. Ferguson (ed.). Pistachio production manual. Univ. Calif., Div. Agr. Natural Resources, Oakland (in press).

California Pistachio Commission. 2001. California pistachio 2000 bearing acreage, production and yield/acre by county and district, p. 68-69. In: California pistachio industry annual report, Crop year 20002001. Calif. Pistachio Comm., Fresno.

Champlain, R.A. and G.D. Butler, Jr. 1967. Temperature effects on development of the egg and nymphal stages of Lygushesperus (Hemiptera:Miridae). Ann. Entomol.Soc. Amer. 60:519-521.

Connell, J.H., J.M. Labavitch, G.S. Sibbett, W.O. Reil, W.H. Barnett, and C. Heintz. 1989. Early harvest of almonds to circumvent late infestation by navel orangeworm. J. Amer. Soc. Hort. Sci. 1 14:595-599.

Daane, K.M., S.A. Steffan, P.G. da Silva, G.Y.Yokota, T.J. Michailides, W.J. Bentley, and R.H. Beede. 2003. Stink bugs and leaffooted bugs. In: L.E. Ferguson (ed.). Pistachio production manual. Univ. Calif., Div. Agr. Natural Resources, Oakland (in press).

Daane, K.M., S.A. Steffan, P.G. da Silva, G.Y. Yokota, K.M. Weir, K. Olsen, E. Hoffman, B.A. Holtz, and W.J. Bentley. 1999. Biological investigations of hemipteran pests to improve control and reduce the spread of the fungus Botryosphaeria dothidea, p. 76-77 In: California pistachio industry annual report, Crop year 19981999. Calif. Pistachio Comm., Fresno.

Daane, K.M., G.Y. Yokota, and R. MalakarKuenen. 2001. Population dynamics of two moth pests, the obliquebanded leafroller and the navel orangeworm, and their parasitoids in pistachio orchards, $\mathrm{p}$. 146-147. In: California pistachio industry annual report, Crop year 2000-2001. Calif. Pistachio Comm., Fresno.

Doster, M.A., T.J. Michailides, D.A. Goldhamer, and D.P. Morgan. 2001. Insufficient spring irrigation increases abnormal splitting of pistachio nuts. Calif. Agr $55: 28-31$.

Doster, M.A. and T.J. Michailides. 1999. Relationship between shell discoloration of pistachio nuts and incidence of fungal decay and insect infestation. Plant Dis. 83:259-264

Doster, M.A. and T.J. Michailides. 1994. Aspergillus molds and aflatoxins in pistachio nuts in California. Phytopathology 84:583-590.

Engle, C.E. and M.N. Barnes. 1983. Developmental threshold temperature and 
heat unit accumulation required for egg hatch of navel orangeworm (Lepidoptera, Pyralidae). Environ. Entomol. 12:12151217.

Ferguson, L. 1998. The California pistachio industry. Acta Hort. 470:38-42.

Goodell, P.B., S.D. Wright, and M.W.F. Carter. 2000. Managing western tarnished plant bug in a regional context. Proc. Beltwide Cotton Prod. Res. Conf. 2:11231125.

Goodell, P.B. and W.J. Bentley. 2003. Lygus bugs. In: L.E. Ferguson (ed.). Pistachio production manual. Univ. Calif., Div. Agr. Natural Resources, Oakland (in press).

Holtz, B., S. Sibbett, C. Kallsen, L. Hendricks, R. Beede, T. Michailides, M. Doster, G. Weinberger, C. Wylie, and J. Bassett. 2001a. Evaluation of pruning and fungicide sprays to control Botryosphaeria Blight, p. 170-171. In: California pistachio industry annual report, Crop year 2000-2001. Calif. Pistachio Comm., Fresno.

Holtz, B., T. Michailides, E. Hoffman, C. Wylie, R. Paslay, and M. Braga. 2001b. Fungicide and in-season liquid lime sulfur sprays to control botryosphaeria blight, $\mathrm{p}$. 172-173. In: California pistachio industry annual report, Crop year 2000-2001. Calif. Pistachio Comm., Fresno.

Huisman, O.C. and L.J. Ashworth, Jr. 1974. Quantitative assessment of Verticillium albo-atrum in field soils: procedural and substrate improvements. Phytopathology 64:1043-1044.

Li, S.Y., S.M. Fitzpatrick, and M.B. Isman. 1995. Susceptibility of different instars of the obliquebanded leafroller (Lepidoptera: Tortricidae) to Bacillus thuringiensis var. kurstaki. J. Econ. Entomol. 88(3):610614.

Ma, Z., E.W.A. Boehm, Y. Luo, and T.J. Michailides. 2001a. Population structure of Botryosphaeria dothidea from pistachio and other hosts in California. Phytopathology 91:665-672.

Ma,Z., D.P. Morgan, and T.J. Michailides. $2001 \mathrm{~b}$. Effects of water stress on Botryosphaeria Blight of pistachio caused by Botryosphaeria dothidea. Plant Dis. 85:745-749.
Morgan, D.P., L. Epstein, and L. Ferguson. 1992. Verticillium wilt resistance in pistachio rootstock cultivars: Assays and an assessment of two interspecific hybrids. Plant Dis. 76:310-313.

Michailides, T.J. 1991. Pathogenicity, distribution, sources of inoculum, and infection courts of Botryosphaeria dothidea on pistachio. Phytopathology 81:566-573.

Michailides, T.J. 2003. Foliar and fruit fungal diseases. In: L.E. Ferguson (ed.). Pistachio production manual. Univ. Calif., Div. Agr. Natural Resources, Oakland (in press).

Michailides, T.J. and D.P. Morgan. 1990. Etiology and transmission of stigmatomycosis of pistachio in California, p. 88-95. In: California pistachio industry annual report, Cropyear 1989-1990. Calif. Pistachio Comm., Fresno.

Michailides, T.J. and D.P. Morgan. 1992. Effects of temperature and wetness duration on infection of pistachio by Botryosphaeria dothidea and management of disease by reducing duration of irrigation. Phytopathology 82:1399-1406.

Michailides, T.J. and D.P. Morgan. 1993. Spore release by Botryosphaeria dothidea in pistachio orchards and disease control by altering the trajectory angle of sprinklers. Phytopathology 83:145-152.

Michailides, T.J., D.P. Morgan, and D. Felts. 1997. Spread of Botryosphaeria dothidea in central California pistachio orchards. Acta Hort. 470:582-591.

Michailides, T.J., D.P. Morgan, and D.A. Goldhamer. 1996. Using subsurface drip irrigation to reduce alternaria late blight of pistachio caused by Alternaria alternata, p. 129-136. In: California pistachio industry annual report, Crop year 1995-1996. Calif. Pistachio Comm., Fresno.

Michailides, T.J., R.E. Rice, and J.M. Ogawa. 1987. Succession and significance of several hempiterans attacking a pistachio orchard. J. Econ. Entomol. 80:398406.

Onstad, D.W., W.H. Reissig, and C.A. Shoemaker. 1985. Phenology and management of the obliquebanded leafroller (Lepidoptera: Tortricidae) in apple orchards. J. Econ. Entomol. 78(6):14551462.
Purcell, M. and S.C. Welter. 1990. Seasonal phenology and biology of Calocoris norvegicus (Hempitera: Miridae) in pistachio and associated host plants. J. Econ. Entomol. 83:1841-1846.

Purcell, M. and S.C. Welter. 1991. Effect of Calocoris norvegicus (Hempitera: Miridae) on pistachio yields. J. Econ. Entomol. 84:114-119.

Raabe, R.D. and S. Wilhelm. 1978. Susceptibility of several Pistacia species to Verticillium albo-atrum. Plant Dis. Rptr. 62:672-673.

Rice, R.E. 2003. Neurocolpusand Calocoris. In: L.E. Ferguson (ed.). Pistachio production manual. Univ. Calif., Div. Agr. Natural Resources, Oakland (in press).

Rice, R.E., W.J. Bentley, and R.H. Beede. 1988a. Hemiptera, p.9-19. In: Insect and mite pests of pistachios in California. Univ. Calif., Div. Agr. Natural Resources, Publ. 21452.

Rice, R.E., D.L. Flaherty, and R.A. Jones. 1988b. The obliquebanded leafroller: A new pest in pistachios. Calif. Agr. 42(1):2729.

Rice, R.E., T.W. Johnson, J.C. Profita, and R.A. Jones. 1984. Improved attractant for navel orangeworm (Lepidoptera: Pyralidae) egg traps in almonds. J. Econ. Entomol. 77:1352-1353.

Rice, R.E., J.K. Uyemoto, J.M. Ogawa, and W.M. Pemberton. 1985. New findings on pistachio problems. Calif. Agr. 39(1):15-18.

Sanderson, J.P. and M.M. Barnes. 1990. Ability of egg traps to detect the onset of second generation navel orangeworm (Lepidoptera: Pyralidae) moth activity in almond orchards. J. Econ. Entomol. 83:570-573.

Sibbett, G.S. and R.A. Van Steenwyk. 1993. Shredding "mummy" walnuts is key to destroying navel orangeworm in winter. Calif. Agr. 47(5):26-28.

Zalom, F.G., J.H. Connell, and W.J. Bentley. 1998. Validation of phenology models for predicting development of the navel orangeworm Ameylois transitella (Walker) in California almond orchards. Acta Hort. 470:525-533. 